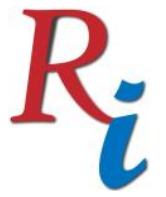

Asia Proceedings of Social Sciences

(APSS)

www.readersinsight.net/APSS

\title{
VIDEO TUTORIAL LEARNING IN COMPUTER THE \\ DEVELOPMENT OF EARLY AGE CHILDREN IN OPEN \\ UNIVERSITY JAKARTA
}

Tin Gustina*

Departement of Educational Technology

Universitas Negeri Jakaarta

Indonesia

\section{Zulfiati Syahrial}

Departement Of Educational Technology

Universitas Negeri Jakarta

Indonesia

\section{Robinson Situmorang}

Departement of Educational Technology

Universitas Negeri Jakarta

Indonesia

*Corrosponding author's Email: bunda.fitri@yahoo.co.id

Peer-review under responsibility of $3^{\text {rd }}$ Asia International Multidisciplanry Conference 2019 editorial board

(http://www.utm.my/asia/our-team/)

(C) 2019 Published by Readers Insight Publisher,

lat 306 Savoy Residencia, Block 3 F11/1,44000 Islamabad. Pakistan,

info@ readersinsight.net

This is an open access article under the CC BY-NC-ND license (http://creativecommons.org/licenses/by-nc-nd/4.0/). 


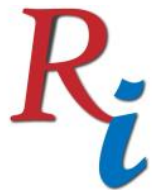

\section{Asia Proceedings of Social Sciences \\ (APSS) \\ www.readersinsight.net/APSS}

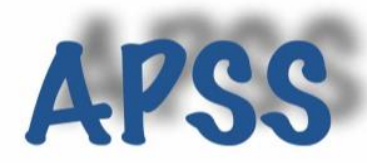

Rese a r ch H i g h I igh t s

Background of the problem about teaching learning process was not effective and be a problem for the lecturer in computer subject at Universitas Terbuka Jakarta. Purpose of this research is to develop teaching media video tutorial to improve students' understanding in material at early childhood education students programs of Universitas Terbuka Jakarta academic year 2018/2019 and to know validity/practical teaching media video tutorial toward learning ability process. Furthermore, this research used research and development method. Population dan sampleof this research is early childhood education programs 8th semester students of Universitas Terbuka Jakarta academic year 2017/2018. Discerning learning media video tutorials are very helpful for students in the learning process.

Keyword: Teaching Media,Video Tutorial, Reserachand Development.

\section{Research Objectives}

Use of video tutorial media in learning is very useful, because with media use students can give feedback, comment on and also be able to remember more about the material presented. According to Cecep and Bambang (2011: 34), learning media in the form of videos can be classified into types of Audio Visual Aids (AVA) or media that can be seen and heard. Sanaky Hujair (2010: 105) explains that audio visual media is a set ofaudible tools that can project movingimagesand. Audio-visual technology is a way of delivering material using the help of mechanical and electronic devices, to present audio-visual messages.

According to (Zubaeti, Budianto, \& Maryono, 2017) Video is an audio and visual learning material that can be used for sending messages or recieving messages. This means that Video is an audio and visual learning material that can be used to send messages or receive messages. Rusman (2012: 210) describes the tutorial is defined as a form of special learning with mentors who are qualified, the use of micro computers for learning tutorial. Tutorials with alternative methods include reading, demonstration, reading discoveries or experiences that require verbal and written responses and exams. Departing from the explanation above, it can be explained that the video tutorial is a guidance for learning in the form of giving direction, assistance, guidance and motivation so that students learn efficiently and effectively.

Many software are used to make tutorial videos such as autodesk investors, Camstudio, and blank discs. In this case the video tutorial used by researchers as a teaching media is made using Camstudio software.

\section{Methodology}

Based on the problems and objectives of the research formulated in the previous section, the approach used in this study is research and development ( $R \& D)$ research.

\section{Population.}

The population in this study were students of the 8th semester of the Jakarta Open University teaching 2018/2019.

\section{Sampling Techniques}

According to Sugiyono (2013: 118) the sample is part of the number and characteristics

possessed by the population. The sample taken in this study is Systematic Sampling, which is a sampling technique based on a sequence of members of the population that have been given a multiple serial number of five. 


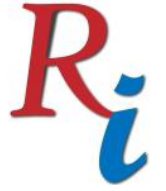

Asia Proceedings of Social Sciences

(APSS)

www.readersinsight.net/APSS

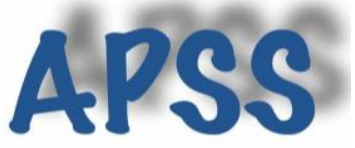

Learning media tutorial videos with simulations that have been designed and made allow students or readers to be able to learn independently and more easily, because it can be used to study wherever and whenever.media

\section{Results}

Learningtutorial videos with simulations that have been made have several features, which include learning material that corresponds to the Module, there is an evaluation that serves to measure the extent of students' ability to learn. Besides learning video tutorial media with simulations there are also simulations that help students in learning.

Learning video tutorial media with simulations that have been made are then validated to Determine the feasibility of the media. Learning media for tutorial videos with simulations was validated, then the learning media of tutorial videos with this simulation were tested on students in the form of practical testing.

\section{Findings}

Development of Video Tutorial learning media with simulations following procedures and development (Research and Development) developed.

The use of video tutorial media in learning is very useful, because with the use of media students can give responses, comment on and also be able to better remember the material presented.

Based on the above explanation it can be concluded that the development of learning media Tutorial videos are very helpful for students in the learning process.

\section{Acknowledgement}

Thanks to God Almighty for all its protection, the writing of this research can be solved

\section{References}

Rusman. 2012. Belajar dan Pembelajaran Berbasis Komputer. Bandung: Alfabeta.

Sugiyono. 2013. Metode Penelitian Pendidikan. Bandung: Alfabeta.

Cecep dan Bambang.2011.Pendekatan Kontruktivitas Dalam Proses Pembelajaran. Jakarta: Rineka Cipta.

Zubaeti, K. R., Budianto, A., \& Maryono, D. (2017). Simple Additive Weighting Method in the Development of a System Assessing the Feasibility of Job Training Industry. Indonesian Journal of Informatics Education, 1(2), 17-28. 